\title{
Ancestral Caddo Ceramic Sherds from 2016 Investigations at 41MR211, Marion County, Texas
}

Timothy K. Perttula

Heritage Research Center, Stephen F. Austin State University

Follow this and additional works at: https://scholarworks.sfasu.edu/ita

Part of the American Material Culture Commons, Archaeological Anthropology Commons, Environmental Studies Commons, Other American Studies Commons, Other Arts and Humanities Commons, Other History of Art, Architecture, and Archaeology Commons, and the United States History Commons

Tell us how this article helped you.

This Article is brought to you for free and open access by the Center for Regional Heritage Research at SFA ScholarWorks. It has been accepted for inclusion in Index of Texas Archaeology: Open Access Gray Literature from the Lone Star State by an authorized editor of SFA ScholarWorks. For more information, please contact cdsscholarworks@sfasu.edu. 


\section{Ancestral Caddo Ceramic Sherds from 2016 Investigations at 41MR211, Marion County, Texas}

\section{Creative Commons License}

\section{(c) (1) \&}

This work is licensed under a Creative Commons Attribution-NonCommercial 4.0 International License 


\title{
Ancestral Caddo Ceramic Sherds from 2016 Investigations at 41MR211, Marion County, Texas
}

\author{
Timothy K. Perttula
}

Renewed archaeological investigations in 2016 by the Texas Historical Commission at the early $19^{\text {th }}$ century Caddo site 41MR211 recovered a small number of ancestral Caddo ceramic vessel sherds from a variety of contexts in Locus 3 (Table 1), which is located just east of the main 1999 excavation block (Figure 1). The sherds are from grog-tempered (70 percent) and shell-tempered (30 percent) vessels. In the larger vessel sherd assemblage $(n=368)$ reported by Parsons et al. (2002a, 2002b) from 41MR211, 36.8 percent of the sherds are from shell-tempered vessels and 59.4 percent are from vessels made with grog temper.

Table 1. Ancestral Caddo sherds recovered in Locus 3 at 41MR211.

Provenience Sherd Description and Thickness

Coll. \#8

Coll. \#9

Coll. \#11

Coll. \#13

Coll. \#19

Coll. \#24

Coll. \#26

Coll. \#27

Coll. \#35

Coll. \#38

Coll. \#39

Coll. \#44

M-11, 0-33 cm

$\mathrm{M}-15,0-20 \mathrm{~cm}$

M-17, 0-20 cm

M-26, 0-10 cm

TU-2, 10-20 cm

TU-2, $13 \mathrm{~cm}$

E397714 N3633190, $5 \mathrm{~cm}$

ST? MD Probe? $16 \mathrm{~cm}$
1 plain grog-tempered body sherd, $7.3 \mathrm{~mm}$

1 plain grog-tempered body sherd, $7.8 \mathrm{~mm}$

1 plain grog-tempered body sherd, $4.9 \mathrm{~mm}$

1 plain shell-tempered body sherd, $6.0 \mathrm{~mm}$

1 grog-tempered base sherd, $8.4 \mathrm{~mm}$

1 grog-tempered overlapping brushed body sherd, $7.4 \mathrm{~mm}$

1 plain shell-tempered body sherd, $6.0 \mathrm{~mm}$

1 plain shell-tempered body sherd, $4.4 \mathrm{~mm}$

1 plain grog-tempered body sherd, $7.1 \mathrm{~mm}$

1 plain grog-tempered body sherd, $8.2 \mathrm{~mm}$

1 plain grog-tempered body sherd, $7.2 \mathrm{~mm}$

1 plain shell-tempered body sherd, $5.2 \mathrm{~mm}$

1 plain grog-tempered body sherd, $6.3 \mathrm{~mm}$

1 plain shell-tempered body sherd, $5.6 \mathrm{~mm}$

1 grog-tempered parallel brushed body sherd, $8.4 \mathrm{~mm}$

1 grog-tempered body sherd with straight incised line, $6.0 \mathrm{~mm}$

1 plain grog-tempered body sherd, $3.9 \mathrm{~mm}$

1 plain grog-tempered body sherd, $4.6 \mathrm{~mm}$

1 plain shell-tempered body sherd, $6.5 \mathrm{~mm}$

1 plain grog-tempered body sherd, $6.8 \mathrm{~mm}$ 


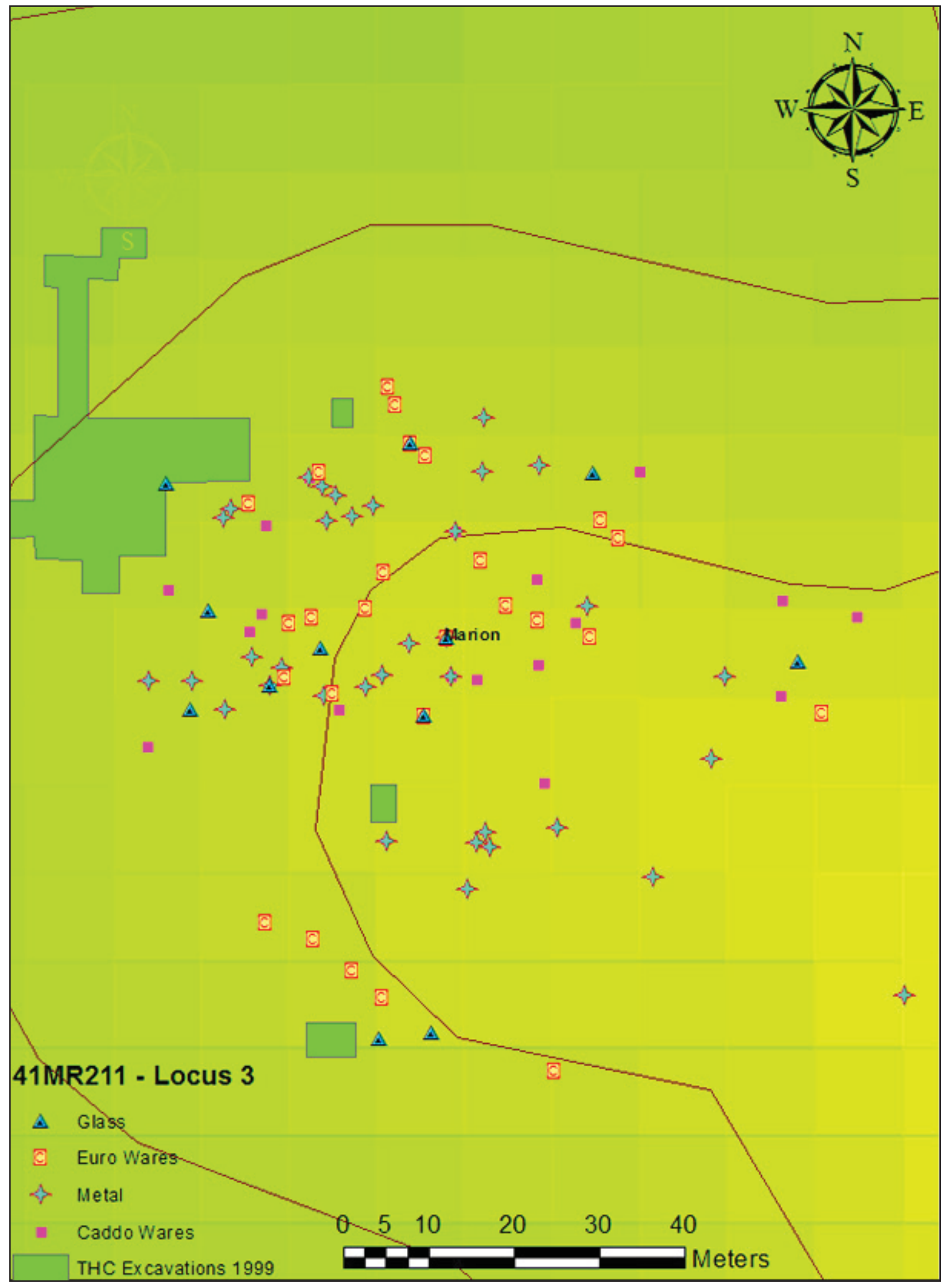

Figure 1. Distribution of ancestral Caddo ceramic sherds in Locus 3 at 41MR211. Figure provided courtesy of Kerry Nichols, Texas Historical Commission. 
Vessel sherds primarily tempered with shell $(n=141)$ in the 41MR211 sherd assemblage are from plain vessels (see Parsons et al. 2002a:Table 1). Only the sherds from 41MR211 vessels primarily tempered with grog $(n=166)$ or bone $(n=69)$ have decorative elements, with engraved, incised, punctated, and incised-punctated sherds prevalent among the grog-tempered wares, and only sherds with brushed decorative elements occur among the bone-tempered wares.

Perttula et al. (2012) have reviewed the age and distribution of shell-tempered ceramics in Caddo sites across the southern Caddo area. In general, shell-tempered ceramics were made by East Texas Caddo potters beginning after ca. A.D. 1300, particularly in McCurtain phase sites along the middle reaches of the Red River; in East Texas McCurtain phase ceramic assemblages, the proportions of shell-tempered sherds ranges from 93-100 percent (see Perttula et al. 2012:Table 1). High proportions of shell-tempered sherds in ceramic assemblages are otherwise only relatively common in post-A.D. 1700 Historic Caddo sites only in the upper Sabine, the Big Cypress Creek basin (as at 41MR211), and in two locales on the Red River, both upstream and downstream from the McCurtain phase sites.

The 20 sherds in this assemblage include 19 body sherds and one base sherd; vessel walls on the body sherds range from 4.4-8.4 $\mathrm{mm}$ in thickness, and the one grog-tempered base sherd is $8.4 \mathrm{~mm}$ thick. Three of the body sherds, each from a utility ware vessel, in this assemblage have decorative elements (see Table 1): two sherds with either overlapping or parallel brushing marks (on a grog-tempered ware; 19 percent of the brushed sherds in the larger assemblage from 41MR211 are grog-tempered) and one sherd with a single straight incised line. The common occurrence of brushed and incised utility wares in a notable characteristic of the previously analyzed ceramic vessel sherds from 41MR211: of the 63 decorated sherds reported by Parsons et al. (2002a, 2002b), 60.3 percent have brushing marks and 15.9 percent have incised decorative elements; the remainder of the decorated sherds have engraved (15.9 percent), punctated (3.2 percent), and incised-punctated (3.2 percent) elements (Parsons et al. 2002a:Table 1).

Although the sample of ancestral Caddo ceramic vessel sherds recovered from Locus 3 in 2016 at 41MR211 is small, it closely resembles the assemblage recovered from the site in the 1999 investigations by the Texas Historical Commission in several ways. First, the range of temper inclusions used in vessel manufacture (i.e., primarily grog, but with a substantial proportion of shell-tempered wares) is consistent in both samples, and second, both assemblages have a high percentage of brushed and incised utility wares. This suggests that the ceramics recovered in Locus 3 are the product of the same ca. A.D. 18001838 ancestral Caddo occupation investigated elsewhere at 41MR211.

\section{References Cited}

Parsons, M. L., J. Bruseth, J. Bagur, and C. McCrocklin

2002a Finding Sha'chahdinnih (Timber Hill): The Last Village of the Kadohadacho in the Caddo Homeland. Plains Anthropologist 47(182):231-249.

Parsons, M. L., J. E. Bruseth, J. Bagur, S. E. Goldborer, and C. McCrocklin

2002b Finding Sha'chahdinnih (Timber Hill): The Last Village of the Kadohadacho in the Caddo Homeland. Archeological Reports Series No. 3. Texas Historical Commission, Austin.

Perttula, T. K., M. B. Trubitt, and J. S. Girard

2012 The Use of Shell-Tempered Pottery in the Caddo Area of the Southeastern United States. Southeastern Archaeology 30(2):242-267. 